\title{
Carbon and nitrogen fluxes in the marine coccolithophore Emiliania huxleyi grown under different nitrate concentrations
}

\author{
Athanasios Kaffes ${ }^{\text {a }}$, Silke Thoms ${ }^{\text {a,* }}$, Scarlett Trimborn ${ }^{a}$, Björn Rost ${ }^{a}$, Gerald Langer ${ }^{\mathrm{b}}$, Klaus-Uwe Richter ${ }^{\mathrm{a}}$, \\ Angela Köhler ${ }^{\mathrm{a}}$, Alessandra Norici ${ }^{\mathrm{c}}$, Mario Giordano ${ }^{\mathrm{c}}$ \\ a Alfred Wegener Institute for Polar and Marine Research, Am Handelshafen 12, 27570 Bremerhaven, Germany \\ b Institute of Environmental Science and Technology (ICTA), Universidad Autònoma de Barcelona (UAB), Bellaterra, 08193, Spain \\ c Department of Marine Sciences, Università Politecnica delle Marche, 60131 Ancona, Italy
}

\section{A R T I C L E I N F O}

\section{Article history:}

Received 9 March 2010

Received in revised form 11 May 2010

Accepted 7 June 2010

\section{Keywords:}

Calcification

Emiliania huxleyi

Nitrate

Nitrate assimilation

Photosynthesis

\begin{abstract}
A B S T R A C T
Information on interaction of $\mathrm{C}$ and $\mathrm{N}$ at the cellular level is lacking for ecologically relevant phytoplankton species. We examined the effects of $\mathrm{NO}_{3}^{-}$availability on $\mathrm{C}$ and $\mathrm{N}$ fluxes in the widely distributed marine coccolithophore Emiliania huxleyi. Cells were cultured at replete $(\sim 280 \mu \mathrm{M})$ and ambient $(\sim 10 \mu \mathrm{M}) \mathrm{NO}_{3}^{-}$, the latter representing a typical surface water nitrate concentration of the North Atlantic Ocean during spring. While growth rates and $\mathrm{C}$ to $\mathrm{N}$ ratios were not altered by the $\mathrm{NO}_{3}^{-}$availability, organic $\mathrm{C}$ and $\mathrm{N}$ as well as inorganic $\mathrm{C}$ quotas were reduced under ambient $\mathrm{NO}_{3}^{-}$. Growth at ambient $\mathrm{NO}_{3}^{-}$caused a higher proportion of fixed $\mathrm{C}$ to be allocated to lipids relative to carbohydrates and especially to proteins. Ambient $\mathrm{NO}_{3}^{-}$-grown cells showed lower $\mathrm{V}_{\max }$ of nitrate reductase (NR) and nitrite reductase (NiR) (ambient/replete: $V_{\max }^{\mathrm{NR}}=0.64 / 1.09 \mathrm{fmol} \mathrm{min}^{-1} \mathrm{cell}^{-1}$; $\mathrm{V}_{\max }^{\mathrm{NiR}}=0.3 / 0.56 \mathrm{fmol} \mathrm{min}^{-1}$ cell $^{-1}$ ), whereas they had higher $\mathrm{V}_{\max }$ of glutamine synthetase (GS) and glutamate synthase (GOGAT) (ambient/replete: $\mathrm{V}_{\max }^{\mathrm{GS}}=0.57 / 0.38 \mathrm{fmol} \mathrm{min}^{-1} \mathrm{cell}^{-1} ; \mathrm{V}_{\max }^{\mathrm{GOG}}=3.91 / 2.87 \mathrm{fmol} \mathrm{min}^{-1} \mathrm{cell}^{-1}$ ). In these cells, photosynthetic $\mathrm{O}_{2}$ evolution and $\mathrm{HCO}_{3}^{-}$uptake rates were lower as compared to replete $\mathrm{NO}_{3}^{-}$-grown cells (ambient/replete: $\mathrm{V}_{\max }^{\mathrm{O}_{2}}=6.5 / 12.9 \mathrm{fmol} \mathrm{min}^{-1}$ cell $^{-1} ; \mathrm{V}_{\max }^{\mathrm{HCO}}=2.8 / 8.1 \mathrm{fmol} \mathrm{min}^{-1}$ cell $^{-1}$ ). The $\mathrm{CO}_{2}$ uptake and the maximum light use efficiency of photosynthesis $(\alpha)$ were unaffected by the concentration of $\mathrm{NO}_{3}^{-}$. The affinities of $\mathrm{NR}$ for $\mathrm{NO}_{3}^{-}$, of $\mathrm{NiR}$ for $\mathrm{NO}_{2}^{-}$, of GS for $\mathrm{Glu}$, and of the inorganic carbon uptake system for $\mathrm{HCO}_{3}^{-}$were higher under ambient $\mathrm{NO}_{3}^{-}$(ambient/replete: $\mathrm{K}_{\mathrm{m}}^{\mathrm{NR}}=0.074 / 0.099 \mathrm{mM} ; \mathrm{K}_{\mathrm{m}}^{\mathrm{NiR}}=1.69 / 3.14 \mathrm{mM} ; \mathrm{K}_{\mathrm{m}}^{\mathrm{GS}}=1.62$ / $\left.3.81 \mathrm{mM} ; \mathrm{K}_{\mathrm{m}}^{\mathrm{HCO}_{3}}=195 / 524 \mu \mathrm{M}\right)$. Our data suggest that a concerted regulation of the intracellular $\mathrm{CO}_{2}$ and $\mathrm{NO}_{3}^{-}$concentrations is required to maintain balanced $\mathrm{C}$ and $\mathrm{N}$ metabolic fluxes resulting in a constant $\mathrm{C}$ to $\mathrm{N}$ ratio.
\end{abstract}

(c) 2010 Elsevier B.V. All rights reserved.

\section{Introduction}

Assimilation of $\mathrm{C}$ and $\mathrm{N}$ consume the largest part of ATP and reductants generated in the cell (Huppe and Turpin, 1994). Although competing for energy, the acquisition and metabolism of $\mathrm{C}$ and $\mathrm{N}$ must be tightly coupled. This is due to the fact that the boundaries of the $\mathrm{C}$ to $\mathrm{N}$ ratio are defined by the stoichiometry of key components of the cell machinery, such as amino acids, proteins, nucleic acids and chlorophylls (Turpin, 1991 and references therein). The relative size of the different pools, within the above mentioned boundaries, is determined by the $\mathrm{N}$ availability relative to $C$ in the environment (Giordano et al., 2001; Palmucci and Giordano, submitted for publication).

Much information on $\mathrm{NO}_{3}^{-}$assimilation is available for model microalgae such as Chlamydomonas reinhardtii (Fernandez and

\footnotetext{
* Corresponding author. Tel.: + 49 47148311801; fax: + 4947148311425 E-mail address: Silke.Thoms@awi.de (S. Thoms).
}

Galvan, 2008 and references therein), but very little is known for ecologically relevant phytoplankton species. In this study, we focused on the widely distributed coccolithophore Emiliania huxleyi (Winter et al., 1994). This organism provides an important contribution to the marine primary production and it is considered to be one of the major producers of calcite in the ocean (Baumann et al., 2004). Very limited data has been published on the $\mathrm{NO}_{3}^{-}$acquisition by E. huxleyi (Page et al., 1999; Riegman et al. 2000). Some data are available for E. huxleyi nitrate reductase (NR), which shows some unique properties compared to the NR proteins of other microalgae (Iwamoto and Shiraiwa, 2003). Native E. huxleyi NR has an overall mass of $514 \mathrm{kD}$ and is composed of six $85 \mathrm{kD}$ homologous subunits (Iwamoto and Shiraiwa, 2003). The $\mathrm{K}_{\mathrm{m}}$ for NADH and $\mathrm{NO}_{3}^{-}$of purified NR were $40 \mu \mathrm{M}$ and $104 \mu \mathrm{M}$, respectively (Iwamoto and Shiraiwa, 2003). No information is available for E. huxleyi nitrite reductase (NiR), the enzyme responsible for the subsequent reduction of $\mathrm{NO}_{2}^{-}$to $\mathrm{NH}_{4}^{+}$. The $\mathrm{NH}_{4}^{+}$ generated thanks to the catalysis by NiR is incorporated into amino acids via the glutamine synthetase/ glutamate synthase (GS/GOGAT) cycle. Two different GS isoforms of the enzyme, one located in the 
cytosol $\left(\mathrm{GS}_{1}\right)$, the other located in the chloroplast $\left(\mathrm{GS}_{2}\right)$, have been partially characterized in E. huxleyi by Maurin and Le Gal (1997a). Both isoforms are homohexamers with molecular masses of $402 \mathrm{kD}$ for $\mathrm{GS}_{1}$ and $501 \mathrm{kD}$ for $\mathrm{GS}_{2}$, whereas the molecular masses of the subunits of $\mathrm{GS}_{1}$ and $\mathrm{GS}_{2}$ were estimated to be 61 and $70 \mathrm{kD}$, respectively (Maurin and Le Gal, 1997a). The same authors reported that the $\mathrm{K}_{\mathrm{m}}$ for hydroxylamine $\left(\mathrm{NH}_{2} \mathrm{OH}\right)$ was approximately $3 \mathrm{mM}$ for both GS isoforms, but $\mathrm{GS}_{2}$ had higher affinity for Gln than $\mathrm{GS}_{1}$. Maurin and Le Gal (1997b) also showed that E. huxleyi total GS activity was stimulated by decreasing $\mathrm{NO}_{3}^{-}$availability and the affinity of GS for $\mathrm{NH}_{4}^{+}$was higher in $\mathrm{N}$ limited cells. In contrast to GS, no data is available in the literature for E. huxleyi GOGAT. The synthesis of amino acids via the GS/GOGAT system typically requires $C$ skeletons from the TCA cycle (Elfiri and Turpin, 1986; Weger and Turpin, 1989).

Almost the entire $C$ contained in macromolecular compounds such as proteins and lipids is fixed by Rubisco. Since Rubisco is characterized by a low affinity for $\mathrm{CO}_{2}$, microalgae cells have to invest a substantial amount of energy to enhance $\mathrm{CO}_{2}$ concentration at the carboxylation site of Rubisco and avoid inorganic carbon ( $\mathrm{Ci}$ ) limitation (Badger et al., 1998). Therefore, cells have developed biophysical and, possibly, biochemical carbon concentrating mechanisms (CCMs) that operate to increase the availability of $\mathrm{CO}_{2}$ for Rubisco (Giordano et al., 2005a and references therein). While it has been shown that the photosynthetic $C$ acquisition of $E$. huxleyi was regulated in response to light and $\mathrm{CO}_{2}$ (Rost et al., 2003; Rost et al., 2006; Trimborn et al., 2007), the effect of $\mathrm{N}$ availability on the CCM has not been studied in this species. The CCMs have been suggested to improve $\mathrm{N}$-use efficiency in microalgae, mainly by increasing the achieved rate of $\mathrm{CO}_{2}$ fixation per unit $\mathrm{N}$ in Rubisco (Raven, 1997; Beardall et al., 1998), thereby controlling the cellular elemental ratios, specifically the $\mathrm{C}$ to $\mathrm{N}$ ratio (Beardall and Giordano, 2002).

In this study, we intend to gain a better understanding of the regulation of intracellular processes that define the $\mathrm{C}$ to $\mathrm{N}$ ratio in a common phytoplankton cell. With this aim in mind, we investigated the regulation of cellular $\mathrm{C}$ and $\mathrm{N}$ fluxes and the relative composition of macromolecular pools in response to $\mathrm{NO}_{3}^{-}$availability in E. huxleyi.

\section{Materials and methods}

\subsection{Culture conditions}

The coccolith-bearing strain B 92/11 (J. C. Green 1990, Plymouth Marine Laboratory) of $E$. huxleyi was grown in semi continuous cultures in $10 \mathrm{~L}$ polycarbonate flasks. Experiments were carried out under a 16:8 h light:dark (LD) cycle at a constant temperature of $15^{\circ} \mathrm{C}$. The applied mean photon flux density was $240 \mu \mathrm{mol}$ photons $\mathrm{m}^{-2} \mathrm{~s}^{-1}$. The culture flasks were aerated with air containing a $\mathrm{CO}_{2}$ partial pressure $\left(\mathrm{pCO}_{2}\right)$ of $37.5 \mathrm{~Pa}$ and placed on a shaker, to keep the cells in suspension. The growth medium was prepared from sterilefiltered ( $0.2 \mu \mathrm{m}$ pore-size cellulose-acetate filters, Sartorius) natural seawater. Nutrient additions, with the exception of iron and $\mathrm{NO}_{3}^{-}$, were made according to the $\mathrm{f} / 2$ recipe (Guillard and Ryther, 1962). The iron concentration in the culture medium was $8 \mathrm{nM}$ and was sufficient to cover the iron need of the relative low cell densities in our experiment, as determined in preliminary experiments. Cells were grown in a semi-continuous mode which allowed for relatively constant growth conditions (LaRoche et al., 2010). Over the course of the experiment, cell densities were kept between $3 * 10^{4}$ cells $\mathrm{mL}^{-1}$ (after dilution) and $3^{*} 10^{5}$ cells $\mathrm{mL}^{-1}$ (before dilution). The initial $\mathrm{NO}_{3}^{-}$ concentrations in the growth media were ca. $280 \mu \mathrm{M}$ in the replete and ca. $10 \mu \mathrm{M}$ in the ambient $\mathrm{NO}_{3}^{-}$treatment (Fig. 1a). Generally, cells were harvested at a density of $3^{*} 10^{5}$ cells $\mathrm{mL}^{-1}$. Cells grown at the ambient $\mathrm{NO}_{3}^{-}$concentration were harvested before the onset of growth limitation (Fig. 1b). Growth rates and cell volume were calculated from daily cell counts by means of a cell counter (COULTER
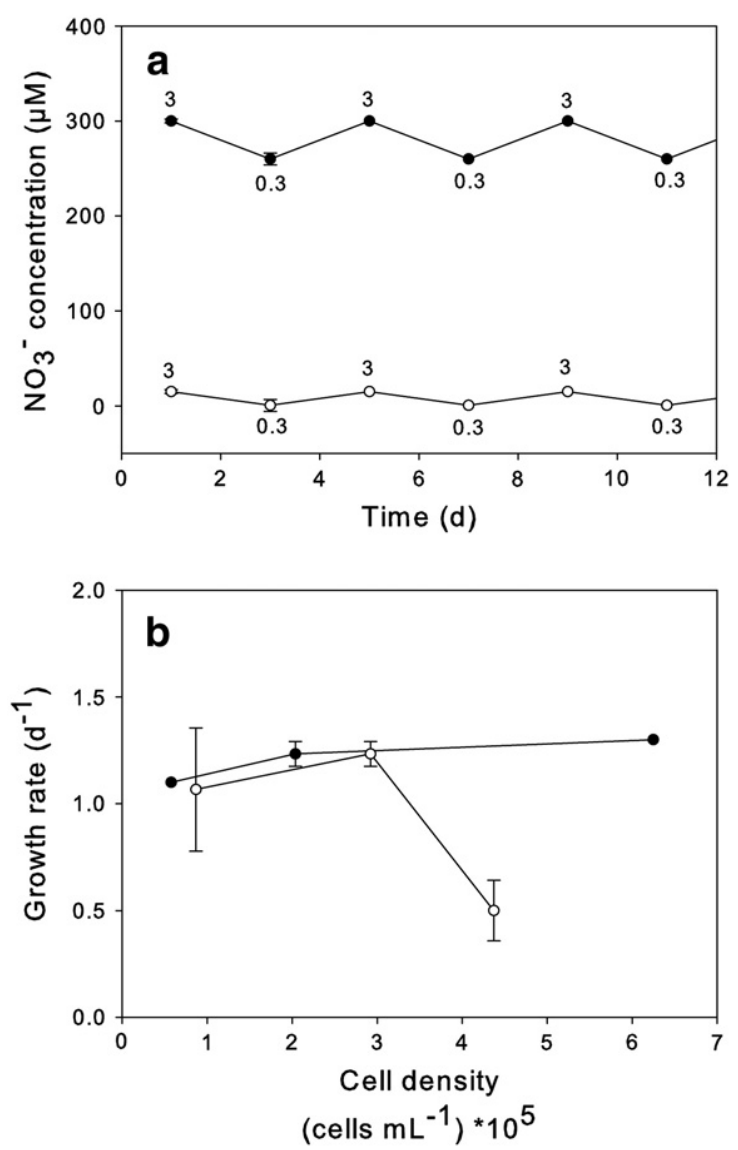

Fig. 1. The variability of $\mathrm{NO}_{3}^{-}$concentrations over the course of the experiment (cell densities are shown with numbers in units of $10^{5}$ cells $\mathrm{mL}^{-1}$ ) (1a) and the relationship between growth rates and cell densities in cells grown at replete $(\bullet)$ and ambient $(\mathrm{O})$ $\mathrm{NO}_{3}^{-}$(1b). Incremental growth rates were calculated on the basis of daily cell counts. Values represent an average of triplicates $( \pm S D)$.

MULTISIZER 3, Beckmann). Before measurements, cells were acclimated to the experimental conditions for at least $14 \mathrm{~d}$.

\subsection{Elemental composition and coccolith morphology}

Samples for total particulate C (TPC), particulate organic C (POC) and $\mathrm{N}(\mathrm{PON})$ were filtered on precombusted $\left(500^{\circ} \mathrm{C}, 12 \mathrm{~h}\right)$ filters (nominal pore size $0.6 \mu \mathrm{m}$ GFF filters, Whatman) and stored in precombusted $\left(500{ }^{\circ} \mathrm{C}, 12 \mathrm{~h}\right.$ ) petri-dishes at $-20^{\circ} \mathrm{C}$. Filters for POC were treated before analysis with $200 \mu \mathrm{HCl}(0.1 \mathrm{M})$ to remove all inorganic C. TPC, POC and PON samples were measured on an elemental analyzer mass spectrometer (ANCA-SL 2020, Sercon). Values for particulate inorganic carbon (PIC) were calculated as the difference between TPC and POC. Regarding the morphology of coccoliths, samples for scanning electron microscope analysis were filtered on polycarbonate filters $(0.2 \mu \mathrm{m}$ pore size, Whatman), dehydrated in a drying cabinet at $60^{\circ} \mathrm{C}$ for 24 hours, then sputtercoated with gold-palladium. Imaging was performed with a digital scanning field-emission electron microscope (XL-30, Philips). Four categories were used to describe the morphology of $E$. huxleyi coccoliths: 'normal', 'malformed', 'incomplete', and 'incomplete and malformed'. An average of approx. 350 coccoliths was analyzed per sample.

\subsection{Macromolecular pools}

The relative amounts of macromolecular pools were determined via Fourier Transform Infrared (FTIR) spectroscopy analysis. Cells for FTIR spectroscopy analyses were harvested by centrifugation at 
$1,500 \times g$ for 15 minutes and washed twice with an isoosmotic solution of ammonium formate, to minimize the carry-over of IR absorbing medium components. Cells were resuspended in ammonium to obtain the concentration that was preliminary determined to afford the best signal to noise ratio. Aliquotes of $50 \mu \mathrm{L}$ of these suspensions were deposited on silica windows (Crystran Ltd., Poole, UK) and desiccated in an oven at $60{ }^{\circ} \mathrm{C}$ for at least 3 hours. Silica windows on which $50 \mu \mathrm{L}$ of ammonium formate solution were deposited were treated as the samples and used as blanks (Domenighini and Giordano, 2009).

FTIR spectra were acquired with a Tensor 27 FTIR spectrometer (Bruker Optics, Ettlingen, Germany) as described in Domenighini and Giordano (2009). All spectra were baseline corrected prior to any analysis by the application of the Rubberband correction function of the OPUS 6.5 software (Bruker Optics, Ettlingen, Germany); they were then normalized to the amide I band $\left(\sim 1650 \mathrm{~cm}^{-1}\right)$. Bands were assigned to the macromolecular pools according to Giordano et al. (2001). The sum of the integrals of the absorption bands at $\sim 1160 \mathrm{~cm}^{-1}, \sim 1080 \mathrm{~cm}^{-1}$ and $\sim 1030 \mathrm{~cm}^{-1}$ was used as a proxy for carbohydrates. The amide I peak $\left(1650 \mathrm{~cm}^{-1}\right)$ was used as an indicator of protein relative abundance. The $\sim 1740 \mathrm{~cm}^{-1}$ feature was used for lipids. Relative ratios of protein, carbohydrates and lipids were calculated from the bands' integrals, using the OPUS 6.5 software (Bruker Optik GmbH, Ettlingen, Germany). The calculation of the band integrals was performed after deconvolution of the spectrum from $1800 \mathrm{~cm}^{-1}$ to $1000 \mathrm{~cm}^{-1}$ using the Peak fit function of OPUS 6.5; to minimize subjective assessments, the main peaks on which deconvolution was based were identified by the application to each spectrum of a second derivative, with 9 smoothing points.

\subsection{Enzymes of nitrate assimilation}

NR activity in phytoplankton often exhibit diurnal variations when grown in a LD cycle. To allow a direct comparison of enzyme activities between cells grown under replete and ambient $\mathrm{NO}_{3}^{-}$concentrations, the samples were taken at the same time of day for both $\mathrm{NO}_{3}^{-}$treatments. The cells were harvested during the fourth hour of the photoperiod. Cells were concentrated by centrifugation at $2,772 \times \mathrm{g}$ for 6 min at $4{ }^{\circ} \mathrm{C}$ (Megafuge $1.0 \mathrm{R}$, Heraeus), frozen in liquid $\mathrm{N}_{2}$ and stored at $-80^{\circ} \mathrm{C}$. The cells were gently disrupted at $4{ }^{\circ} \mathrm{C}$, using a hand operated glass homogenizer (Wheatman). The extracts were then centrifuged at $16,060 \times \mathrm{g}$ for $15 \mathrm{~min}$ at $4^{\circ} \mathrm{C}$ (Biofuge fresco, Heraeus), in order to spin down the calcite. The supernatant was centrifuged again at $61,740 \mathrm{~g}$ for 20 min at $4{ }^{\circ} \mathrm{C}$ (OPTIMA ${ }^{\mathrm{TM}}$ LE-80 KUltracentrifuge, Beckmann) to get rid most of the cell membrane fractions. The resulting supernatant was used to study enzyme kinetics and measure total protein amount. The protein amount in extracts was measured according to the method of Bradford (1976), using BSA as standard. All solutions were made in Milli-Q $\mathrm{H}_{2} \mathrm{O}$ (Milli-Q academic A10, Millipore) and the chemicals were purchased by Sigma-Aldrich (St. Louis, MO, USA).

\subsubsection{NR activity}

$\mathrm{NR}$ activity was determined by $\mathrm{NO}_{3}^{-}$reduction to $\mathrm{NO}_{2}^{-}$and subsequent colorimetric measurement of the $\mathrm{NO}_{2}^{-}$produced according to the method described by Giordano et al. (2005b). The extraction buffer for NR (buffer A) contained 50 mM HEPES (pH 7.5), $1 \mathrm{mM}$ EDTA, $1 \mathrm{mM}$ dithiothreitol, 0.1\% Triton X-100 (v/v), 0.3\% polyvinylpolypyrrolidone $(\mathrm{w} / \mathrm{v})$ and $10 \mathrm{mM} \mathrm{MgSO}_{4}$. The amount of $\mathrm{NO}_{2}^{-}$was measured according to the method of Snell and Snell (1949) in a microplate reader (SPECTRAFLUOR, Tecan) at $535 \mathrm{~nm}$. Controls included the same reaction mixture, but extraction buffer was used instead of extract. The amount of $\mathrm{NO}_{2}^{-}$in the tubes was quantified according to a $\mathrm{NO}_{2}^{-}$standard curve from 0 to $40 \mu \mathrm{M}$. Nitrate concentrations from 0.005 to $20 \mathrm{mM}$ were used for the determination of NR kinetic parameters.

\subsubsection{NiR activity}

Activities of NiR were determined using an assay described by Wray and Filner (1970), which is based on the colorimetric measurement of the $\mathrm{NO}_{2}^{-}$left in the reaction mixture. Buffer A was used for NiR extraction and the reaction was run in open tubes. The assay mixture contained in a total volume of $500 \mu \mathrm{L}$ : $100 \mu \mathrm{L}$ of $150 \mathrm{mM}$ phosphate buffer ( $\mathrm{pH} 7.5$ ), $20 \mu \mathrm{L}$ Milli-Q $\mathrm{H}_{2} \mathrm{O}, 250 \mu \mathrm{L}$ of $32 \mathrm{mM} \mathrm{NaNO}_{2}$, $5 \mu \mathrm{L}$ of a $100 \mathrm{mM}$ methyl viologen solution, $50 \mu \mathrm{L}$ of extract and $75 \mu \mathrm{L}$ of fresh $\mathrm{Na}_{2} \mathrm{~S}_{2} \mathrm{O}_{4}\left(25 \mathrm{mg} \mathrm{mL}^{-1} \mathrm{Na}_{2} \mathrm{~S}_{2} \mathrm{O}_{4}\right.$ in $\left.0.29 \mathrm{M} \mathrm{NaHCO}_{3}\right)$ solution. This mixture was incubated at $30{ }^{\circ} \mathrm{C}$ for $15 \mathrm{~min}$. The reaction was initiated by adding the sodium dithionite solution. The reaction was stopped by vigorous shaking until the dithionite was completely oxidized and the solution turned from dark blue to colourless. Controls included the same reaction mixture, but extraction buffer was used instead of extract. The amount of $\mathrm{NO}_{2}^{-}$was measured in a microplate reader (SPECTRAFLUOR, Tecan) at $535 \mathrm{~nm}$ according to the method of Snell and Snell (1949) with a standard curve from 0 to $40 \mu \mathrm{M} \mathrm{NO}_{2}^{-}$. Nitrite concentrations from 0.25 to $16 \mathrm{mM}$ were used in the assay, in order to determine the NiR kinetic parameters.

\subsubsection{GS activity}

GS activity was determined from the formation of L-Glu $\gamma$ monohydroxamate as described by O’Neal and Joy (1973), and Oaks et al (1980). The extraction buffer for GS (buffer B) contained $50 \mathrm{mM} \mathrm{HEPES}$ (pH 7.5), 1 mM EDTA, 2 mM dithiothreitol, 0.1\% Triton X-100 (v/v), 0.3\% polyvinylpolypyrrolidone $(\mathrm{w} / \mathrm{v})$ and $10 \mathrm{mM} \mathrm{MgSO}_{4}$. The extracts were desalted by applying them on a Sephadex column (PD-10 DESALTING COLUMN, GE Healthcare, Uppsala, Sweden). The extracts were eluted using $50 \mathrm{mM}$ HEPES (pH 7.5). An assay mixture containing $160 \mathrm{mM}$ HEPES (pH 7.5), $4.8 \mathrm{mM}$ hydroxylamine ( $\mathrm{pH} 7.5$ ), $3.2 \mathrm{mM} \mathrm{MgSO}_{4}$ and $0.16 \mathrm{mM}$ EDTA was prepared. The reaction was conducted in a 96-well plate in a final volume of $200 \mu \mathrm{L}$. To a $76.4 \mu \mathrm{l}$ aliquot of the assay mixture, we added $25.6 \mu \mathrm{L}$ of $6.25 \mathrm{mM}$ ATP $(\mathrm{pH} 7.5)$ and $76.8 \mu \mathrm{L}$ extract. The reactants were incubated for $5 \mathrm{~min}$ at $30^{\circ} \mathrm{C}$. At last, $21.2 \mu \mathrm{L}$ of $0.6 \mathrm{M}$ Glu were added, the microplate was incubated for $20 \mathrm{~min}$ at $30^{\circ} \mathrm{C}$. The reaction was terminated by adding $40 \mu \mathrm{L}$ of a $\mathrm{FeCl}_{3}$ solution $\left[2.5 \% \mathrm{FeCl}_{3}\right.$ $(\mathrm{w} / \mathrm{v}), 5 \% \mathrm{TCA}(\mathrm{w} / \mathrm{v}), 1.5 \mathrm{~N} \mathrm{HCl}]$. The reactants were centrifuged at $16,060 \times \mathrm{g}$ for $2 \mathrm{~min}$. Controls were run, in which $50 \mathrm{mM}$ HEPES ( $\mathrm{pH} 7.5$ ) was used instead of extract. A second control was run, in which the reaction was stopped by adding the $\mathrm{FeCl}_{3}$ solution immediately after the Glu addition. The amount of L-Glu $\gamma$-monohydroxamate was measured in a microplate reader at $535 \mathrm{~nm}$ with a standard curve from 0 to $25 \mu \mathrm{M}$ $\gamma$-L-Glu monohydroxamate. Glu concentrations from 0.5 to $63.6 \mathrm{mM}$ and hydroxylamine $\left(\mathrm{NH}_{2} \mathrm{OH}\right)$ concentrations from 0.02 to $4.8 \mathrm{mM}$ were used to derive GS kinetic parameters.

\subsubsection{GOGAT activity}

GOGAT activity was determined by the reduction in the absorbance of NADH similar to the methods of Singh and Srivastava (1986) and Lin and Kao (1996). Buffer A was used for GOGAT extraction. The assay mixture contained $125 \mathrm{mM}$ HEPES ( $\mathrm{pH} 7.5$ ), $5 \mathrm{mM}$ EDTA, $20 \mathrm{mM} \mathrm{KCl}$ and $875 \mu \mathrm{M} \mathrm{NADH}$. The reaction was conducted in a 96well plate in a final volume of $250 \mu \mathrm{L}$. To a $50 \mu \mathrm{l}$ aliquot of the assay mixture, we added $100 \mu \mathrm{L}$ extract, $50 \mu \mathrm{L}$ of $20 \mathrm{mM}$ Gln and $50 \mu \mathrm{L}$ of $5 \mathrm{mM} \alpha$-ketoglutarate. Controls included the same reaction mixture, in which the extract was substituted with extraction buffer. The reduction in NADH absorbance at $340 \mathrm{~nm}$ was measured in a microplate reader (SPECTRAFLUOR, Tecan) at $30{ }^{\circ} \mathrm{C}$ for $2 \mathrm{~min}$, immediately after the addition of $\alpha$-ketoglutarate.

\subsection{Photosynthesis and $\mathrm{Ci}$ acquisition}

Ci fluxes during steady-state photosynthesis were investigated by means of a sector-field multicollector mass spectrometer (ISOPRIME, GV Instruments, Manchester, UK). Net photosynthesis was measured by monitoring the $\mathrm{O}_{2}$ concentration over consecutive LD intervals 
with increasing $\mathrm{Ci}$ concentrations ( 0 to $\sim 5 \mathrm{mM}$ ). Light and dark intervals during the assay lasted 6 min. Simultaneous measurements of the $\mathrm{CO}_{2}$ concentration enabled us to determine the $\mathrm{CO}_{2}$ uptake and $\mathrm{HCO}_{3}^{-}$uptake kinetics according to equations by Badger et al. (1994), using a photosynthetic quotient (PQ) of 1.4 (Williams and Robertson, 1991). To provide conditions similar to the acclimation, all measurements were performed at $15^{\circ} \mathrm{C}$ in buffered f/2 medium $(50 \mathrm{mM}$ HEPES, pH 8.0) with $\mathrm{NO}_{3}^{-}$concentrations of 300 and $10 \mu \mathrm{M}$, respectively. Dextran-bound sulfonamide (DBS), a membrane-impermeable inhibitor of carbonic anhydrase, was added to the cuvette to a final concentration of $100 \mu \mathrm{M}$. Chl a concentration ranged between 0.5 and $1 \mathrm{mg} \mathrm{mL}^{-1}$. The incident photon flux density was $300 \mu \mathrm{mol}$ photons $\mathrm{m}^{-2} \mathrm{~s}^{-1}$. For further details on the method and calculation, we refer to Badger et al. (1994) and Rost et al. (2007). The kinetic parameters $\mathrm{V}_{\max }$ and $\mathrm{K}_{1 / 2}$ were obtained by fitting the data with a Michaelis-Menten equation.

Furthermore, net photosynthesis was measured under various light intensities ( 0 to $800 \mu \mathrm{mol}$ photons $\mathrm{m}^{-2} \mathrm{~s}^{-1}$ ). While the same buffer (HEPES $50 \mathrm{mM}, \mathrm{pH} 8.0$ ) and respective $\mathrm{NO}_{3}^{-}$concentrations (300 versus $10 \mu \mathrm{M}$ ) were used as in the Ci flux assay measurements, the $\mathrm{Ci}$ concentration were kept at $\sim 2 \mathrm{mM}$. This way rates of photosynthesis, both expressed in terms of $\mathrm{O}_{2}$ evolution and carbon fixation, could be measured as a function of PFD. The light-saturated photosynthetic rate as a function of irradiance (E) was calculated from the equation

$$
V=V_{\max }\left(1-\exp \left(-\frac{\alpha}{V_{\max }}(E-E k)\right)\right)
$$

where $\mathrm{V}$ is the rate of photosynthesis, $\mathrm{V}_{\max }$ is the maximal rate of photosynthesis and $\mathrm{E}_{\mathrm{k}}$ is the light compensation point. The unit of the maximum light use efficiency of photosynthesis $(\alpha)$ is $\mu \mathrm{mol}$ $\mathrm{O}_{2}(\mathrm{mg} \mathrm{Chl} a)^{-1} \mathrm{~h}^{-1}\left(\mu \mathrm{mol} \text { photon } \mathrm{m}^{-2} \mathrm{~s}^{-1}\right)^{-1}$.

\subsection{Statistical analysis}

All data were statistically analyzed using the t-test (one-tailed) with a confidence level of $95 \%$ (see Table S1 in the Supplementary Material).

\section{Results}

\subsection{Growth, elemental composition and coccolith morphology}

The growth rates were quite similar (1.1 to $1.2 \mathrm{~d}^{-1}$ ) for the two $\mathrm{NO}_{3}^{-}$ treatments. The cell volume, however, was one-forth lower in cells at ambient $\mathrm{NO}_{3}^{-}$(Table 1; Table $\mathrm{S} 1$ ). At ambient $\mathrm{NO}_{3}^{-}$, cells accumulated less organic $\mathrm{C}$ and $\mathrm{N}$ and the cellular POC content was ca. one-third lower (Table 1; Table S1). Similarly, cells grown at ambient $\mathrm{NO}_{3}^{-}$ contained one-third less PON than their high $\mathrm{NO}_{3}^{-}$counterparts (Table. 1; Table S1). Despite changes in POC and PON content, the $\mathrm{C}$ to $\mathrm{N}$ ratio remained constant and was about 8.3 to 8.5 in both $\mathrm{NO}_{3}^{-}$ treatments (Table 1; Table S1). The cellular PIC content was approximately one-fourth lower at ambient $\mathrm{NO}_{3}^{-}$(Table 1; Table S1). The PIC to POC ratio was 0.6 to 0.7 (as can be calculated from the POC and PIC values in Table 1) and remained constant irrespective of the $\mathrm{NO}_{3}^{-}$levels in the experiment. Cells produced mostly incomplete coccoliths when grown at ambient $\mathrm{NO}_{3}^{-}$(Figs. 2 and 3). In contrast,

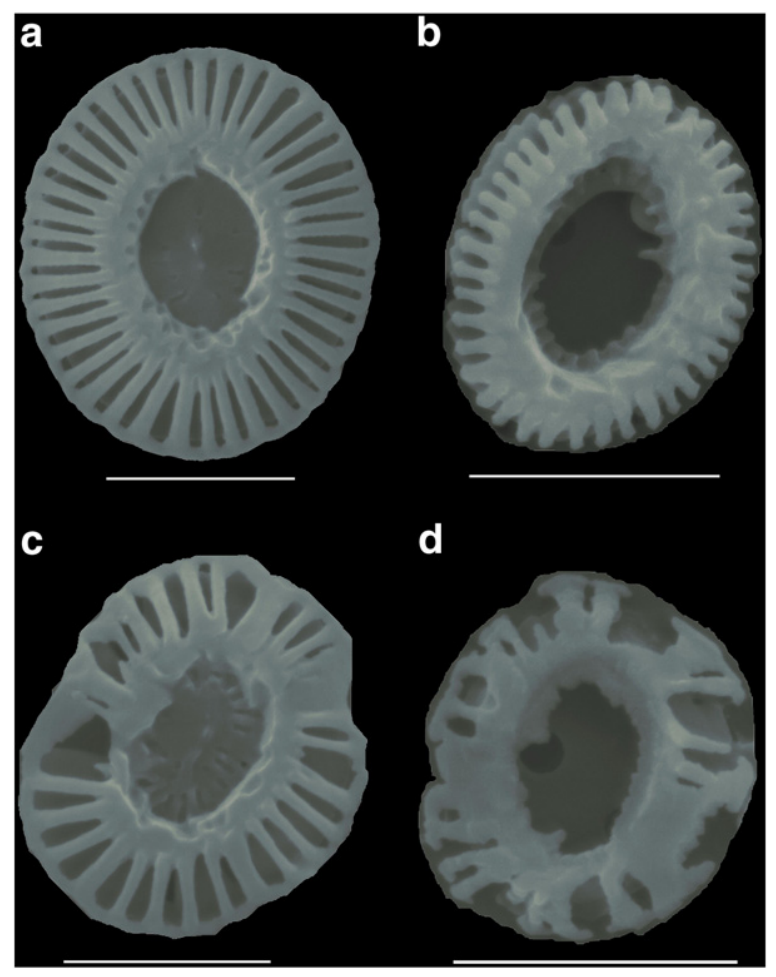

Fig. 2. Scanning electron microscopy images of coccoliths of E. huxleyi. All scalebars $2 \mu \mathrm{m}$. All specimens in distal view. (a) normal coccolith. (b) incomplete coccolith. (c) malformed coccolith. (d) incomplete and malformed coccolith.

almost all coccoliths produced by cells at replete $\mathrm{NO}_{3}^{-}$were normal (Figs. 2 and 3).

\subsection{Macromolecular pools}

The allocation of $\mathrm{C}$ into the macromolecular compounds was affected by the $\mathrm{NO}_{3}^{-}$condition in the culture medium. Cells in the ambient $\mathrm{NO}_{3}^{-}$treatment were characterized by ca. one-third lower protein content (Table 1; Table S1). The abundance of proteins relative to lipids, as determined by FTIR spectroscopy, was lower at ambient $\mathrm{NO}_{3}^{-}$; the opposite was true for the proteins to carbohydrates and lipids to carbohydrates (Table 2; Table S1). The comparison of the FTIR data with the absolute protein determinations allows to conclude that at ambient $\mathrm{NO}_{3}^{-}$, the lower protein content is accompanied by an even more obvious reduction of the carbohydrate pool, whereas the lipid pool appears to be affected by the growth treatment. Although, the relative nature of FTIR measurements performed for this work makes it impossible to determine the extent of these variations.

\subsection{Enzymes of nitrate assimilation}

$\mathrm{N}$ availability was found to affect the kinetics of both NR and NiR (Figs. S1 and 2). NR $\mathrm{V}_{\max }$ was 1.7-fold lower in cells at ambient $\mathrm{NO}_{3}^{-}$ compared to cells grown at replete $\mathrm{NO}_{3}^{-}$, when it was expressed on a cell basis (Table 3; Table S1). When expressed on a protein basis, cell volume, $\mathrm{C}$ or $\mathrm{N}, \mathrm{NR} \mathrm{V}_{\max }$ was basically unaffected by the $\mathrm{NO}_{3}^{-}$ concentration in the medium. The affinity of $\mathrm{NR}$ for $\mathrm{NO}_{3}^{-}$was

Table 1

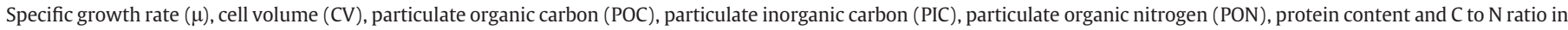
cells grown at replete and ambient $\mathrm{NO}_{3}^{-}$. The values represent the means of triplicate incubations $( \pm \mathrm{SD})$.

\begin{tabular}{|c|c|c|c|c|c|c|c|}
\hline $\mathrm{NO}_{3}^{-}(\mu \mathrm{M})$ & $\mu\left(\mathrm{d}^{-1}\right)$ & $\mathrm{CV}\left(\mu \mathrm{m}^{3}\right)$ & POC (pg cell $\left.{ }^{-1}\right)$ & PIC (pg cell $\left.{ }^{-1}\right)$ & PON (pg cell ${ }^{-1}$ ) & Protein (pg cell ${ }^{-1}$ ) & $\mathrm{C}$ to $\mathrm{N}$ ratio $\left(\mathrm{mol} \mathrm{mol}^{-1}\right)$ \\
\hline Replete & $1.2 \pm 0.1$ & $394 \pm 46$ & $13.9 \pm 2.4$ & $8.7 \pm 0.9$ & $1.9 \pm 0.2$ & $1.7 \pm 0.1$ & $8.5 \pm 0.5$ \\
\hline Ambient & $1.1 \pm 0.2$ & $272 \pm 37$ & $9.3 \pm 0.8$ & $6.6 \pm 0.9$ & $1.3 \pm 0.1$ & $1.2 \pm 0.1$ & $8.3 \pm 0.9$ \\
\hline
\end{tabular}




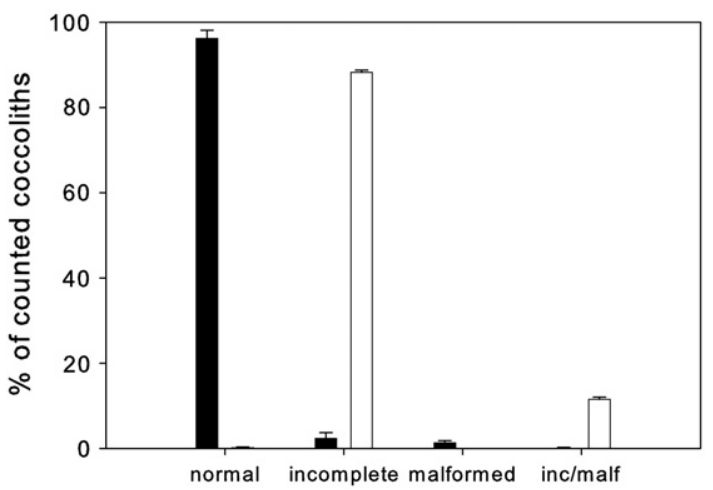

Fig. 3. Percentage of normal, malformed, incomplete, and incomplete and malformed (inc/malf) coccoliths in cells grown at replete ( $\square$ ) and ambient ( $\square$ ) $\mathrm{NO}_{3}^{-}$. Values represent an average of duplicates $( \pm S D)$.

significantly higher in cells at ambient $\mathrm{NO}_{3}^{-}$(Table 3; Table S1). Regardless of the basis on which it was expressed, $\mathrm{NiR}_{\mathrm{max}}$ was lower at ambient $\mathrm{NO}_{3}^{-}$(Table 3; Table S1). The affinity of $\mathrm{NiR}^{2}$ for $\mathrm{NO}_{2}^{-}$was substantially higher at ambient $\mathrm{NO}_{3}^{-}$(Table 3; Table S1).

The different $\mathrm{NO}_{3}^{-}$concentrations also affected GS kinetics (Fig. S3). At ambient $\mathrm{NO}_{3}^{-}, \mathrm{GS} \mathrm{V}_{\max }$ was higher and this relationship was independent of the type of normalization (Table 3; Table S1). Regarding total GS affinities, the affinity for Glu was two-fold higher in cells grown at ambient $\mathrm{NO}_{3}^{-}$than in their counterparts (Table 3; Table S1). The affinity of total GS for $\mathrm{NH}_{2} \mathrm{OH}$ was similar in cells of both $\mathrm{NO}_{3}^{-}$treatments (Table 3; Table $\mathrm{S} 1$ ). Similar to GS $\mathrm{V}_{\max }$, GOGAT $\mathrm{V}_{\text {max }}$ was higher in cells grown at the ambient $\mathrm{NO}_{3}^{-}$regime, irrespective of the parameter on which the enzyme activity was expressed (Table 3; Table S1).

\subsection{Photosynthesis and $\mathrm{Ci}$ acquisition}

The maximum rate of net photosynthesis expressed on a per cell basis was about two-fold lower in cells at ambient $\mathrm{NO}_{3}^{-}$(Table 4; Table S1; Fig. S4). When net photosynthesis was expressed on a mg Chl $a$ basis, no difference was observed between cells of the high and low $\mathrm{NO}_{3}^{-}$treatment. This is a consequence of the fact that the amount of Chl $a$ was about two-fold lower in cells at ambient $\mathrm{NO}_{3}^{-}$(data not shown). However, at ambient $\mathrm{NO}_{3}^{-}$, the affinities of photosynthesis for $\mathrm{CO}_{2}$ and DIC were higher (Table 4; Table S1; Fig. S4). The light curve of net photosynthesis revealed that maximum light use efficiency of photosynthesis $(\alpha)$ was similar between the two $\mathrm{NO}_{3}^{-}$treatments (Table 4; Table S1).

Maximum gross $\mathrm{CO}_{2}$ uptake (uptake of $\mathrm{CO}_{2}$ into the cell) and net $\mathrm{CO}_{2}$ uptake (gross $\mathrm{CO}_{2}$ uptake minus $\mathrm{CO}_{2}$ efflux) rates $\left(\mathrm{V}_{\max }\right)$ per cell were similar in high and low $\mathrm{NO}_{3}^{-}$-grown cells (Table 4; Table S1; Fig. S5A and SB). The affinities of net and gross $\mathrm{CO}_{2}$ uptake for $\mathrm{CO}_{2}$ were not affected by the different $\mathrm{NO}_{3}^{-}$conditions (Table 4; Table $\mathrm{S} 1$ ). The effects of $\mathrm{N}$ availability were stronger on the uptake of $\mathrm{HCO}_{3}^{-}$(Fig. S6). The rate of $\mathrm{HCO}_{3}^{-}$uptake was ca. four-fold lower in cells at ambient $\mathrm{NO}_{3}^{-}$(Table 4; Table $\mathrm{S} 1$ ). Whereas the rate of $\mathrm{HCO}_{3}^{-}$uptake

\section{Table 2}

FTIR absorbance ratios of proteins to lipids, proteins to carbohydrates and lipids to carbohydrates in cells grown in the presence of either replete or ambient $\mathrm{NO}_{3}^{-}$ concentrations. Values represent an average of triplicates $( \pm S D)$, except for the ratios of proteins to lipids, for which $n=4$. Please note that values of the ratios based on FTIR spectroscopy measurements represent absorbance ratios and not amount ratios.

\begin{tabular}{llll}
\hline $\mathrm{NO}_{3}^{-}(\mu \mathrm{M})$ & $\begin{array}{l}\text { Proteins to } \\
\text { lipids ratio }\end{array}$ & $\begin{array}{l}\text { Proteins to carbohydr. } \\
\text { ratio }\left(10^{-4}\right)\end{array}$ & $\begin{array}{l}\text { Lipids to carbohydr. } \\
\text { ratio }\left(10^{-5}\right)\end{array}$ \\
\hline Replete & $15.5 \pm 1.22$ & $2.38 \pm 0.54$ & $1.3 \pm 0.1$ \\
Ambient & $11.6 \pm 2.26$ & $2.72 \pm 0.65$ & $3.0 \pm 0.8$ \\
\hline
\end{tabular}

Table 3

Kinetics $\mathrm{V}_{\text {max }}$ and $\mathrm{K}_{\mathrm{m}}$ of NR, NiR and GS, as well as GOGAT $\mathrm{V}_{\text {max }}$ in cells grown at replete and ambient $\mathrm{NO}_{3}^{-}$. All values represent the means of triplicates $( \pm \mathrm{SD})$. In the kinetics of $\mathrm{GS}$ for $\mathrm{NH}_{2} \mathrm{OH}(\mathrm{n}=4)$.

\begin{tabular}{|c|c|c|c|c|}
\hline $\mathrm{NO}_{3}^{-}(\mu \mathrm{M})$ & & & Replete & Ambient \\
\hline \multirow[t]{2}{*}{ NR } & $\mathrm{V}_{\max }$ & fmol NO $2-$ min $^{-1}$ cell $^{-1}$ & $1.09 \pm 0.25$ & $0.64 \pm 0.06$ \\
\hline & $\mathrm{K}_{\mathrm{m}}\left(\mathrm{NO}_{3}^{-}\right)$ & $\mathrm{mM}$ & $0.099 \pm 0.013$ & $0.074 \pm 0.007$ \\
\hline \multirow[t]{2}{*}{$\mathrm{NiR}$} & $\mathrm{V}_{\max }$ & fmol $\mathrm{NO}_{2}^{-} \min ^{-1}$ cell $^{-1}$ & $0.56 \pm 0.05$ & $0.3 \pm 0.01$ \\
\hline & $\mathrm{K}_{\mathrm{m}}\left(\mathrm{NO}_{2}^{-}\right)$ & $\mathrm{mM}$ & $3.14 \pm 0.6$ & $1.69 \pm 0.43$ \\
\hline \multirow[t]{3}{*}{ GS } & $\mathrm{V}_{\max }$ & $\begin{array}{l}\text { fmol hydroxamate } \\
\text { min }^{-1} \text { cell }^{-1}\end{array}$ & $0.385 \pm 0.11$ & $0.57 \pm 0.04$ \\
\hline & $\mathrm{K}_{\mathrm{m}}(\mathrm{Glu})$ & $\mathrm{mM}$ & $3.812 \pm 1.63$ & $1.621 \pm 0.372$ \\
\hline & $\mathrm{K}_{\mathrm{m}}\left(\mathrm{NH}_{2} \mathrm{OH}\right)$ & $\mathrm{mM}$ & $0.095 \pm 0.035$ & $0.092 \pm 0.023$ \\
\hline GOGAT & $\mathrm{V}_{\max }$ & fmol NADH min $^{-1}$ cell $^{-1}$ & $2.87 \pm 0.18$ & $3.91 \pm 0.76$ \\
\hline
\end{tabular}

decreased, the affinity of $\mathrm{HCO}_{3}^{-}$uptake increased in cells grown at ambient $\mathrm{NO}_{3}^{-}$(Table 4; Table S1). The rate of respiration expressed on a per cell basis was similar in high and low $\mathrm{NO}_{3}^{-}$-grown cells (Table 4; Table S1). When respiration was expressed on organic $\mathrm{C}$ or cell volume basis, its rate was higher in cells at ambient $\mathrm{NO}_{3}^{-}$.

\section{Discussion}

Although $\mathrm{C}$ and $\mathrm{N}$ quotas and cell volume were lower at ambient than at replete $\mathrm{NO}_{3}^{-}$, growth rates and $\mathrm{C}$ to $\mathrm{N}$ ratios were similar for the two growth regimes used for this study (Table 1 ). The constant $\mathrm{C}$ to $\mathrm{N}$ ratio and the results obtained by FTIR spectroscopy suggest that the abundance of protein relative to the non-nitrogenous pools examined (i.e. carbohydrates and lipids) was not affected by the ambient $\mathrm{NO}_{3}^{-}$ treatment, and the lower protein content was simply the consequence of the lower $\mathrm{C}$ and $\mathrm{N}$ quotas. However, a shift occurred in the $\mathrm{C}$ partitioning between lipids and carbohydrates: the fraction of $\mathrm{C}$ allocated to lipids was appreciably higher than that located to carbohydrates (which became less abundant), when $\mathrm{NO}_{3}^{-}$availability was lower (Table 2). A similar allocation pattern was also observed for cells of the marine diatom Chaetoceros muellerii by Giordano et al. (2001). The greater proportional allocation of $C$ to lipids than to carbohydrates at ambient $\mathrm{NO}_{3}^{-}$occured together with a higher respiration rate (on an organic $\mathrm{C}$ and volume basis) measured in ambient $\mathrm{NO}_{3}^{-}$-grown cells. Lipid biosynthesis would in fact require more energy and TCA cycle intermediates then carbohydrate production (Norici and Giordano, 2002; Montechiaro and Giordano, 2009). The shift of cell composition towards a higher lipid content relative to carbohydrate, in low $\mathrm{NO}_{3}^{-}$-grown cells, may be related to the fact that these smaller cells benefit from the higher volume-, C- and mass-based energy content of lipid (Schmidt-Nielsen, 1997; Raven, 2005). The observed macromolecular composition may also have contributed to

\section{Table 4}

Kinetics $\mathrm{V}_{\max }$ and $\mathrm{K}_{1 / 2}$ of net photosynthesis, maximum light use efficiency of photosynthesis $(\alpha)$, kinetics of gross $\mathrm{CO}_{2}$ uptake, net $\mathrm{CO}_{2}$ uptake and $\mathrm{HCO}_{3}^{-}$uptake, as well as respiration in cells grown at replete and ambient $\mathrm{NO}_{3}^{-}$. For net photosynthesis, gross and net $\mathrm{CO}_{2}$ uptake, $\mathrm{HCO}_{3}^{-}$uptake and respiration in cells grown at replete $\mathrm{NO}_{3}^{-}$ $(n=5)$. All other values represent the means of triplicates $( \pm S D)$.

\begin{tabular}{|c|c|c|c|c|}
\hline $\mathrm{NO}_{3}^{-}(\mu \mathrm{M})$ & & & Replete & Ambient \\
\hline Net & $\mathrm{V}_{\max }$ & fmol $\mathrm{O}_{2} \min ^{-1}$ cell $^{-1}$ & $12.9 \pm 0.7$ & $6.5 \pm 0.8$ \\
\hline \multirow[t]{2}{*}{ photosynthesis } & $\mathrm{K}_{1 / 2}\left(\mathrm{CO}_{2}\right)$ & $\mu \mathrm{M}$ & $4.1 \pm 0.6$ & $2.5 \pm 0.6$ \\
\hline & $\mathrm{K}_{1 / 2}$ (DIC) & $\mu \mathrm{M}$ & $443 \pm 79$ & $263 \pm 57$ \\
\hline$\alpha$ & & $\begin{array}{l}\mu \mathrm{mol} \mathrm{O} \mathrm{O}_{2}(\mathrm{mg} \mathrm{Chl} a)^{-1} \mathrm{~h}^{-1} \\
\left(\mu \mathrm{mol} \text { photon } \mathrm{m}^{-2} \mathrm{~s}^{-1}\right)^{-1}\end{array}$ & $1.5 \pm 0.04$ & $1.7 \pm 0.4$ \\
\hline \multirow[t]{2}{*}{ Gross $\mathrm{CO}_{2}$ uptake } & $\mathrm{V}_{\max }$ & fmol CO${ }_{2} \min ^{-1}$ cell $^{-1}$ & $6.2 \pm 2$ & $5.4 \pm 2$ \\
\hline & $\mathrm{K}_{1 / 2}\left(\mathrm{CO}_{2}\right)$ & $\mu \mathrm{M}$ & $3.5 \pm 0.4$ & $2.6 \pm 0.8$ \\
\hline \multirow[t]{2}{*}{ Net $\mathrm{CO}_{2}$ uptake } & $V_{\max }$ & fmol CO ${ }_{2} \min ^{-1}$ cell $^{-1}$ & $2.05 \pm 0.4$ & $2.8 \pm 0.5$ \\
\hline & $\mathrm{K}_{1 / 2}\left(\mathrm{CO}_{2}\right)$ & $\mu \mathrm{M}$ & $4.5 \pm 2$ & $4.3 \pm 0.6$ \\
\hline \multirow[t]{2}{*}{$\mathrm{HCO}_{3}^{-}$uptake } & $\mathrm{V}_{\max }$ & fmol $\mathrm{HCO}_{3}^{-} \min ^{-1}$ cell $^{-1}$ & $8.1 \pm 3.1$ & $2.8 \pm 0.8$ \\
\hline & $\mathrm{K}_{1 / 2}\left(\mathrm{HCO}_{3}^{-}\right)$ & $\mu \mathrm{M}$ & $524 \pm 180$ & $195 \pm 38$ \\
\hline Respiration & & fmol O${ }_{2} \min ^{-1}$ cell $^{-1}$ & $2.3 \pm 0.4$ & $1.9 \pm 0.1$ \\
\hline
\end{tabular}


the decreased calcite content (Table 1) and higher proportion of incomplete coccoliths (Figs. 2 and 3) observed for low $\mathrm{NO}_{3}^{-}$-grown cells. It has been hypothesized that, under $\mathrm{N}$-deficiency, incomplete coccolith formation may be caused by a shortage of polysaccharides involved in coccolithogenesis and/or to "an inadequate level of some essential $\mathrm{N}$-compound" (e.g. protein) that may affect crystal growth (Paasche, 1998). It is conspicuous that no differences in the percentages of malformed coccoliths were observed (Fig. 3). It is concluded that $\mathrm{N}$-deficiency does not disturb the coccolith-shaping machinery as such. Two components of this machinery have been identified, namely the Coccolith Associated Polysaccharide, CAP (Henriksen et al., 2004; Marsh et al., 2002) and the cytoskeleton (Langer et al., submitted for publication). Hence, the shortage of polysaccharides, hypothesized by Paasche (1998), does not include CAP, nor does the shortage of protein include the cytoskeleton.

Based on the enzyme kinetics measured for NR and the kinetics of net photosynthesis derived from the MIMS measurements, we estimated the intracellular concentrations of $\mathrm{NO}_{3}^{-}$and $\mathrm{CO}_{2}$ which allow for balanced growth, i.e. maintenance of a constant $\mathrm{C}$ to $\mathrm{N}$ ratio. Please note that $\mathrm{C}$ and $\mathrm{N}$ fluxes based on MIMS measurements and NR activity represent instantaneous rates obtained three to four hours after the beginning of the photoperiod, while the $\mathrm{C}$ and $\mathrm{N}$ quotas represent integrated values over a complete LD cycle. For E. huxleyi, no significant differences were found between the integrated $\mathrm{C}$ to $\mathrm{N}$ ratios during exponential growth under continuous light and the ones under LD cycle (Price et al., 1998). During growth under continuous light, fixation of $C$ and $\mathrm{N}$ appear to be closely coupled, hence the primary products of photosynthesis are directly used in biosynthesis rather than for carbon storage (Burkhardt et al., 1999). Under these circumstances, the net fixation rate of $\mathrm{C}\left(\mathrm{C}_{\text {flux }}\right)$ can thus be expressed in terms of the $\mathrm{N}$ assimilation rate $\left(\mathrm{N}_{\text {flux }}\right)$, using the $\mathrm{C}$ to $\mathrm{N}$ ratio:

$$
\frac{\mathrm{C}_{\text {flux }}}{\mathrm{N}_{\text {flux }}}=\frac{\mathrm{POC}}{\mathrm{PON}}
$$

The upper boundary for $\mathrm{C}_{\text {flux }}$ in balance with $\mathrm{N}$ assimilation is provided by the maximum NR activity $\mathrm{V}_{\max }^{\mathrm{NR}}$ and would be obtained at infinite $\mathrm{NO}_{3}^{-}$concentration in the cytosol. Using our result for $\mathrm{V}_{\max }^{\mathrm{NR}}$, the upper limit for $C_{\text {flux }}$ that derives from Eq. (1) is very similar to the maximum net photosynthesis (in terms of $C$ ), which we obtained from the MIMS measurements $\left(\mathrm{V}_{\max }^{\mathrm{CO}_{2}}=\mathrm{V}_{\max }^{\mathrm{O}_{2}} / \mathrm{PQ}\right.$, with PQ being the photosynthetic quotient). For balanced growth to be maintained (Eq.(1)), the upper limit for $C_{\text {flux }}$ must assume a value of $9.3 \mathrm{fmol} \mathrm{min}^{-1}$ cell $^{-1}$ for the replete $\mathrm{NO}_{3}^{-}$condition $(\mathrm{POC} / \mathrm{PON}=8.5)$, and $5.3 \mathrm{fmol} \mathrm{min}^{-1}$ cell $^{-1}$ for cells acclimated to ambient $\mathrm{NO}_{3}^{-}(\mathrm{POC} / \mathrm{PON}=8.3)$. Given the photosynthetic quotient from a $\mathrm{NO}_{3}^{-}$-utilizing cell $(\mathrm{PQ}=1.36$; Williams and Robertson, 1991), the MIMS measurements predict a $\mathrm{V}_{\max }^{\mathrm{CO}_{2}}$ of $9.5 \pm 0.5 \mathrm{fmol} \mathrm{min}^{-1}$ cell $^{-1}$ and $4.8 \pm 0.6 \mathrm{fmol} \mathrm{min}^{-1}$ cell $^{-1}$, for the replete and ambient $\mathrm{NO}_{3}^{-}$conditions, respectively. Hence, the ratios of $\mathrm{V}_{\max }^{\mathrm{CO}_{2}}$ and $\mathrm{V}_{\max }^{\mathrm{NR}}$ are approximately given by the $\mathrm{C}$ to $\mathrm{N}$ ratios for the two growth $\mathrm{NO}_{3}^{-}$concentrations used for this study (high $\mathrm{NO}_{3}^{-}$: $1.0 \mathrm{POC} / \mathrm{PON}$, low $\mathrm{NO}_{3}^{-}$: $0.9 \mathrm{POC} / \mathrm{PON}$ ). Using Eq. (1) and $\mathrm{V}_{\max }^{\mathrm{CO}_{2}} / \mathrm{V}_{\max }^{\mathrm{NR}} \approx$ $\mathrm{POC} / \mathrm{PON}$ it follows that

$$
\frac{\mathrm{C}_{\text {flux }}}{\mathrm{V}_{\max }^{\mathrm{CO}}} \approx \frac{\mathrm{N}_{\text {flux }}}{\mathrm{V}_{\max }^{\mathrm{NR}}}
$$

In the following, we assume for the $\mathrm{C}_{\text {flux }}$ the enzyme activity of Rubisco and for the $\mathrm{N}_{\text {flux }}$ the enzyme activity of NR. Using MichaelisMenten kinetics for the $\mathrm{C}$ and $\mathrm{N}$ fluxes, Eq. (2) yields the condition for balanced growth in terms of the intracellular concentrations of $\mathrm{NO}_{3}^{-}$and $\mathrm{CO}_{2}$

$$
\frac{\left[\mathrm{CO}_{2}\right]}{\mathrm{K}_{\mathrm{Rub}}+\left[\mathrm{CO}_{2}\right]} \approx \frac{\left[\mathrm{NO}_{3}^{-}\right]}{\mathrm{K}_{\mathrm{NR}}+\left[\mathrm{NO}_{3}^{-}\right]}
$$

which can be written as

$$
\left(\frac{\mathrm{K}_{\mathrm{Rub}}}{\left[\mathrm{CO}_{2}\right]}+1\right)^{-1} \approx\left(\frac{\mathrm{K}_{\mathrm{NR}}}{\left[\mathrm{NO}_{3}^{-}\right]}+1\right)^{-1}
$$

Finally, a further simplification of (4) yields

$$
\frac{\left[\mathrm{CO}_{2}\right]}{\mathrm{K}_{\mathrm{Rub}}} \approx \frac{\left[\mathrm{NO}_{3}^{-}\right]}{\mathrm{K}_{\mathrm{NR}}}
$$

with $\mathrm{K}_{\mathrm{Rub}}$ and $\mathrm{K}_{\mathrm{NR}}$ being the Michaelis-Menten constants for Rubisco and NR, respectively.

Generally, for an enzyme possessing the activity $V_{0}$, the ratio of the concentration of the substrate $\mathrm{S}$ and the Michaelis-Menten constant $\mathrm{Km}$ determines the degree of saturation of the enzyme activity $\left(\mathrm{V}_{0} / \mathrm{V}_{\max }=1 /\left(\mathrm{K}_{\mathrm{m}} /[\mathrm{S}]+1\right)\right)$. Based on Eq. (5) it follows that a constant $\mathrm{C}$ to $\mathrm{N}$ ratio can be maintained for intracellular $\left[\mathrm{CO}_{2}\right]$ and $\left[\mathrm{NO}_{3}^{-}\right]$which yield a comparable saturation of the enzyme activity for the enzymes involved in $\mathrm{C}$ and $\mathrm{N}$ assimilation. Hence, the maintenance of a constant $\mathrm{C}$ to $\mathrm{N}$ ratio requires a concerted regulation of the intracellular $\left[\mathrm{CO}_{2}\right]$ and $\left[\mathrm{NO}_{3}^{-}\right]$to equilibrate the fluxes through the $\mathrm{C}$ and $\mathrm{N}$ assimilation pathway. It should be noted that Eq. (5) is valid for all degrees of enzyme saturation $\left(0<\mathrm{V}_{0} / \mathrm{V}_{\max }<1\right)$ in the cells acclimated to the two growth regimes. This flexibility indicates that the maintenance of a constant $\mathrm{C}$ to $\mathrm{N}$ ratio under different growth conditions does not imply constant kinetic properties of the enzymes involved in the $\mathrm{C}$ and $\mathrm{N}$ assimilation pathway. In fact, the availability of $\mathrm{NO}_{3}^{-}$affects the kinetics of $\mathrm{NR}, \mathrm{NiR}$ and net photosynthesis in $E$. huxleyi cells. At ambient $\mathrm{NO}_{3}^{-}$, the $\mathrm{V}_{\max }$ of $\mathrm{NR}, \mathrm{NiR}$ and net photosynthesis was down-regulated compared to cells grown at replete $\mathrm{NO}_{3}^{-}$(Tables 3 and 4), probably as a result of less protein amounts. In cells grown at ambient $\mathrm{NO}_{3}^{-}$, the effect of lower enzyme activity $\left(\mathrm{V}_{\max }\right)$ on the $\mathrm{C}$ and $\mathrm{N}$ flux was weakened by the increase in the affinity of NR, NiR and net photosynthesis for the substrates (Tables 3 and 4). Since the E. huxleyi genome appears to have only one gene encoding for NR (Bruhn et al., 2010) and one encoding for NiR (Wurch), the change in the affinity for the substrates (lower $\mathrm{K}_{\mathrm{m}}$ of NR for $\mathrm{NO}_{3}^{-}$and of $\mathrm{NiR}$ for $\mathrm{NO}_{2}^{-}$at ambient $\mathrm{NO}_{3}^{-}$) cannot be attributed to the expression of different isoforms and must be attributed to posttranslational regulation. The decrease in the $\mathrm{K}_{1 / 2}$ of photosynthesis at ambient $\mathrm{NO}_{3}^{-}$may be related to post-translational regulation or expression of high-affinity $\mathrm{HCO}_{3}^{-}$transporters (Amoroso et al., 2003). The kinetics of GS in E. huxleyi cells are also modified in response to $\mathrm{NO}_{3}^{-}$availability. The higher total GS $\mathrm{V}_{\max }$ in cells at ambient $\mathrm{NO}_{3}^{-}$ (Table 3) may be a response of $\mathrm{NH}_{4}^{+}$re-assimilation after increased proteolysis in cells under $\mathrm{N}$ limiting conditions (Hipkin et al., 1982). The activity of GOGAT showed more or less the same response to $\mathrm{NO}_{3}^{-}$ availability as total GS activity; this is not surprising, since these two enzymes operate sequentially.

In addition to the regulation of $\mathrm{K}_{\mathrm{m}}$, the degree of enzyme saturation is determined by the substrate concentration established at the site of the enzyme. For instance, when the NR activity reaches $80 \%$ of its maximum value, $\mathrm{NO}_{3}^{-}$accumulates in the cytosol, yielding concentrations of $396 \mu \mathrm{M}$ and $296 \mu \mathrm{M}$ for the cells acclimated to high and low $\mathrm{NO}_{3}^{-}$, respectively. For balanced growth to be maintained (Eq. (5)), the $\mathrm{CO}_{2}$ concentration at the site of Rubisco must then exceed $\mathrm{K}_{\mathrm{Rub}}$ by a factor of 4 , for the replete and ambient $\mathrm{NO}_{3}^{-}$ conditions. The values of $K_{\text {Rub }}$ for the two growth conditions are not known. Assuming a $\mathrm{K}_{\text {Rub }}$ of $30 \mu \mathrm{M}$ (Badger et al., 1998), it follows a $\left[\mathrm{CO}_{2}\right]$ at Rubisco of $120 \mu \mathrm{M}$. We assumed steady state conditions for $\mathrm{N}$ assimilation. In other words, the substrates inside the cell accumulate until the rates of reactions are the same for all the 
enzymes involved in the $\mathrm{N}$ assimilation pathway (from $\mathrm{NO}_{3}^{-}$to $\mathrm{NH}_{4}^{+}$ assimilation by GS):

$$
\mathrm{N}_{\text {flux }}=\frac{\mathrm{V}_{\max }^{\mathrm{NR}}\left[\mathrm{NO}_{3}^{-}\right]}{\mathrm{K}_{\mathrm{NR}}+\left[\mathrm{NO}_{3}^{-}\right]}=\frac{\mathrm{V}_{\max }^{\mathrm{NiR}}\left[\mathrm{NO}_{2}^{-}\right]}{\mathrm{K}_{\mathrm{NiR}}+\left[\mathrm{NO}_{2}^{-}\right]}=\frac{\mathrm{V}_{\mathrm{max}}^{\mathrm{GS}}\left[\mathrm{NH}_{4}^{+}\right]}{\mathrm{K}_{\mathrm{GS}}+\left[\mathrm{NH}_{4}^{+}\right]}
$$

Then, the NiR kinetics data predicts an accumulation of high $\mathrm{NO}_{2}^{-}$ concentrations at the site of NiR activity. The requirement for a high $\mathrm{NO}_{2}^{-}$concentration for E. huxleyi NiR suggests that this enzyme is confined in the proximity of the chloroplast envelope, possibly near the entry point of $\mathrm{NO}_{2}^{-}$into the chloroplast. However, high internal $\mathrm{NO}_{2}^{-}$pools of 4 to $5 \mathrm{mM}$ have been reported for the diatom Chaetocheros sp. (Lomas and Glibert, 2000).

The GS could not be used for estimated intracellular $\mathrm{NH}_{4}^{+}$ concentrations in our study. Glutamine synthetase activity was found to be approximately $40 \%$ higher when measured with a radioactive assay with ammonia as substrate in comparison to the colorimetric assay with $\mathrm{NH}_{2} \mathrm{OH}$ as substrate (Listrom et al., 1997). Furthermore, GS activity in microalgae deriving from measurements with the biosynthetic reaction assay was found to be two to three fold higher compared with the enzyme activity from the transferase reaction assay (Bressler and Ahmed, 1984). Therefore the use of $\mathrm{NH}_{2} \mathrm{OH}$ instead of $\mathrm{NH}_{4}^{+}$and/or the application of the GS transferase instead of the biosynthetic assay may be the reasons that do not allow using GS $V_{\max }$ for the estimation of intracellular $\mathrm{NH}_{4}^{+}$concentrations in our study.

In conclusion, $\mathrm{NO}_{3}^{-}$availability seem to have a crucial impact on the regulation of $\mathrm{C}$ and $\mathrm{N}$ fluxes in the marine coccolithophore E. huxleyi, without necessarily changing the $\mathrm{C}$ to $\mathrm{N}$ ratios and/or growth rates of cells. With the exception of GS and GOGAT, cells generally respond to ambient $\mathrm{NO}_{3}^{-}$availability with a down regulation of activities of proteins involved in the acquisition and assimilation of inorganic $\mathrm{C}$ and $\mathrm{N}$. At the same time, the substrate affinities of these proteins increase in response to ambient $\mathrm{NO}_{3}^{-}$. Our study suggests that the intracellular $\mathrm{CO}_{2}$ and $\mathrm{NO}_{3}^{-}$concentrations have to be carefully regulated, in order to equilibrate the fluxes through the $\mathrm{C}$ and $\mathrm{N}$ assimilation pathways, and ensure an adequate growth for the respective $\mathrm{NO}_{3}^{-}$conditions.

\section{Acknowledgements}

We would like to thank Ellen Lichte for technical assistance. The research leading to these results has received funding from the German Research Foundation (DFG) and is part of the project TH 744/ 2-3. This research was also supported by the Spanish Ministry of Education (Juan de la Cierva programme) cofunded by the European Social Fund and Ministry of Science and Innovation. S. Trimborn and B. Rost acknowledge financial support by the European Research Council under the European Community's Seventh Framework Programme (FP7/2007-2013)/ERC grant agreement (205150). [SS]

\section{Appendix A. Supplementary data}

Supplementary data associated with this article can be found, in the online version, at doi:10.1016/j.jembe.2010.06.004.

\section{References}

Amoroso, G., Seimetz, N., Sueltemeyer, D., 2003. The $d c 13$ gene upstream of ictB is involved in rapid induction of the high affinity $\mathrm{Na}^{+}$dependent $\mathrm{HCO}_{3}^{-}$transporter in cyanobacteria. Photosynth. Res. 77, 127-138.

Badger, M.R., Palmqvist, K., Yu, J.W., 1994. Measurement of $\mathrm{CO}_{2}$ and $\mathrm{HCO}_{3}^{-}$fluxes in cyanobacteria and microalgae during steady-state photosynthesis. Physiol. Plant. 90, 529-536.

Badger, M.R., Andrews, T.J., Whitney, S.M., Ludwig, M., Yellwolees, C., Leggat, W., Price G.D., 1998. The diversity and coevolution of Rubisco, plastids, pyrenoids, and chloroplast-based $\mathrm{CO}_{2}$-concentrating mechanisms in microalgae. Can. J. Bot. 76, 1052-1071.
Baumann, K.H., Bockel, B., Frenz, M., 2004. Coccolith contribution to South Atlantik carbonate sedimentation. In: Thierstein, H.R., Young, J.R. (Eds.), Coccolithophores: From Molecular Processes to Global Impact. Springer, Berlin, pp. 367-402.

Beardall, J., Giordano, M., 2002. Ecological implications of microalgal and cyanobacterial $\mathrm{CO}_{2}$ concentrating mechanisms, and their regulation. Funct. Plant Biol. 29, 335-347.

Beardall, J., Johnston, A., Raven, J.A., 1998. Environmental regulation of $\mathrm{CO}_{2}-$ concentrating mechanisms in microalgae. Can. J. Bot. 76, 1010-1017.

Bradford, M.M., 1976. A rapid and sensitive method for the quantitation of microgram quantities of protein utilizing the principle of protein-dye binding. Anal. Biochem. $72,248-254$

Bressler, S.L., Ahmed, S.I., 1984. Detection of glutamine synthetase activity in marine phytoplankton: optimization of the biosynthetic assay. Mar. Ecol. Prog. Ser. 14, 207-217.

Bruhn, A., LaRoche, J., Richardson, K., 2010. Emiliania huxleyi (Prymnesiophyceae): Nitrogen-metabolism genes and their expression in response to external nitrogen sources. J. Phycol. 14, 266-277.

Burkhardt, S., Zondervan, I., Riebesell, U., 1999. Effect of $\mathrm{CO}_{2}$ concentration on C:N:P ratio in marine phytoplankton: A species comparison. Limnol. Oceanogr. 44 (3), 683-690.

Domenighini, A., Giordano, M., 2009. Fourier transform infrared spectroscopy of microalgae as a novel tool for biodiversity studies, species identification, and the assessment of water quality. J. Phycol. 45, 522-531.

Elfiri, I.R., Turpin, D.H., 1986. $\mathrm{NO}_{3}^{-}$and $\mathrm{NH}_{4}^{+}$induced photosynthetic suppression in $\mathrm{N}-$ limited Selenastrum minutum. Plant Physiol. 81, 273-279.

Fernandez, A., Galvan, A., 2008. Nitrate assimilation in Chlamydomonas. Euk. Cell. 7. 555-559.

Giordano, M., Kansiz, M., Heraud, P., Beardall, J., Wood, B., McNaughton, D., 2001. Fourier transform infrared spectroscopy as a novel tool to investigate changes in intracellular macromolecular pools in the marine microalga Chaetoceros muellerii (Bacillariophyceae). J. Phycol. 37, 271-279.

Giordano, M., Beardall, J., Raven, J.A., 2005a. $\mathrm{CO}_{2}$ concentrating mechanisms in algae. Mechanisms, environmental modulation, and evolution. Annu. Rev. Plant Biol. 56, 99-131.

Giordano, M., Chen, Y.B., Koblizek, M., Falkowski, P., 2005b. Regulation of nitrate reductase in Chlamydomonas reinhardtii by the redox state of the plastoquinone pool. Eur. J. Phycol. 40, 345-352.

Guillard, R.R.L., Ryther, J.H., 1962. Studies of marine planktonic diatoms. Can. J. Microbiol. 8, 229-239.

Henriksen, K., Stipp, S.L.S., Young, J.R., Marsh, M.E., 2004. Biological control on calcite crystallization: AFM investigation of coccolith polysaccharide function. Am. Mineral. 89, 1709-1716.

Hipkin, C.R., Everest, S.A., Rees, T.A.V., Syrett, P.J., 1982. Ammonium generation by nitrogen-starved cultures of Chlamydomonas reinhardtii. Planta 154, 587-592.

Huppe, H.C., Turpin, D.H., 1994. Integration of carbon and nitrogen metabolism in plant and algal cells. Annu. Rev. Plant Physiol. 45, 577-607.

Iwamoto, K. Shiraiwa, Y., 2003. Characterization of NADH: nitrate reductase from the coccolithophorid Emiliania huxleyi (Lohman) Hay \& Mohler (Haptophyceae). Mar. Biotechnol. 5, 20-26.

Langer, G., De Nooijer, L, Oetjen, $\mathrm{K}_{\text {. }}$ submitted for publication. On the role of the cytoskeleton in coccolith morphogenesis: the effect of cytoskeleton inhibitors. J. Phycol.

LaRoche, J., Rost, B., Engel, A., 2010. Bioassays, batch culture and chemostat experimentation. In: Riebesell, U., Fabry, V.J., Hansson, L., Gattuso, J.-P. (Eds.), Guide to best practices for ocean acidification research and data reporting, $260 \mathrm{p}$. Luxembourg: Publications Office of the European Union 81-94.

Lin, C.C., Kao, C.H., 1996. Disturbed ammonium assimilation is associated with growth inhibition of roots in rice seedlings caused by NaCl. Plant Growth. Reg. 18, 233-238.

Listrom, C.D., Morizono, H., Rajagopal, B.S., McCann, M.T., Tuchman, M., Allewell, N.M., 1997. Expression, purification, and characterization of recombinant human glutamine synthetase. Biochem. J. 328, 159-163.

Lomas, M.W., Glibert, P.M., 2000. Comparisons of nitrate uptake, storage, and reduction in marine diatoms and flagellates. J. Phycol. 36, 903-913.

Marsh, M.E., Ridall, A.L., Azadi, P., Duke, P.J., 2002. Galacturonomannan and Golgiderived membrane linked to growth and shaping of biogenic calcite. J. Struct. Biol. 139, 39-45.

Maurin, C., Le Gal, Y., 1997a. Isoforms of glutamine synthetase in the marine coccolithophorid Emiliania huxlyei (Prymnesiophyceae). Comp. Biochem. Physiol. 118, 903-912.

Maurin, C., Le Gal, Y., 1997b. Glutamine synthetase in the marine coccolithophorid Emiliania huxleyi (Prymnesiophyceae): regulation of activity in relation to light and nitrogen availability. Plant Sci. 122, 61-69.

Montechiaro, F., Giordano, M., 2009. Effect of prolonged dark incubation on pigments and photosynthesis of the cave-dwelling cyanobacterium Phormidium autumnale (Oscillatoriales, Cyanobacteria). Phycologia 45, 704-710.

Norici, A., Giordano, M., 2002. Anaplerosis in microalgae. Rec. Res. Dev. Plant Phys. 3, 153-164

Oaks, A., Stulen, I., Jones, K., Winspear, M.J., Misra, S., Boesel, I.L., 1980. Enzymes of nitrogen assimilation in maize roots. Planta 148, 477-484.

O`Neal, D., Joy, K.W., 1973. Glutamine synthetase of pea leaves. I. Purification, stabilization and pH optima. Arch. Biochem. Biophys. 159, 113-122.

Paasche, E., 1998. Roles of nitrogen and phosphorus in coccolith formation in Emiliania huxleyi (Prymnesiophyceae). Eur. J. Phycol. 33, 33-42.

Page, S., Hipkin, C.R., Flynn, K.J., 1999. Interactions between ammonium and nitrate in Emiliania huxleyi. J. Exp. Mar. Biol. Ecol. 236, 307-319.

Palmucci, M., Giordano, M., submitted for publication. Carbon allocation in eleven microalgal species cultured at different nitrate concentrations. Eur. J. Phycol. 
Price, L.L., Yin, K., Harrison, P.J., 1998. Influence of continuous light and L:D cycles on the growth and chemical composition of Prymnesiophyceae including coccolithophores. J. Exp. Mar. Biol. Ecol. 223, 223-234.

Raven, J.A., 1997. Inorganic carbon acquisition in marine autotrophs. Adv. Bot. Res. 27, 85-209.

Raven, J.A., 2005. Cellular location of starch synthesis and evolutionary origins of starch genes. J. Phycol. 41, 1070-1072.

Riegman, R., Stolte, W., Noordeloos, A.A.M., Slezak, D., 2000. Nutrient uptake and alkaline phosphatase activity of Emiliania huxleyi (Prymnesiophyceae) during growth under $\mathrm{N}$ and $\mathrm{P}$ limitation in continuous cultures. J. Phycol. 36, 87-96.

Rost, B., Riebesell, U., Burkhardt, S., Sültemeyer, D., 2003. Carbon acquisition of bloomforming marine phytoplankton. Limnol. Oceanogr. 48, 55-67.

Rost, B., Riebesell, U., Sültemeyer, D., 2006. Carbon acquisition of marine phytoplankton: Effect of photoperiod length. Limnol. Oceanogr. 51, 12-20.

Rost, B., Kranz, S.A., Richter, K.-U., Tortell, P.D., 2007. Isotope disequilibrium and mass spectrometric studies of inorganic carbon acquisition by phytoplankton. Limnol. Oceanogr. Methods 5, 328-337.

Schmidt-Nielsen, K., 1997. Animal Physiology: Adaptation and Environment, 5th ed. Cambridge University Press, Cambridge, pp. 1-617.

Singh, R.P., Srivastava, H.S., 1986. Increase in glutamate synthase (NADH) in maize seedlings in response to nitrate and ammonium nitrogen. Physiol. Plant. 66, 413-416.

Snell, F.D., Snell, C.T., 1949. "Colorimetric methods of analysis”, vol. II. Van Nostrand, New York, pp. 804-805.
Trimborn, S., Langer, G., Rost, B., 2007. Effect of varying calcium concentrations and light intensities on calcification and photosynthesis in Emiliania huxleyi. Limnol. Oceanogr. 52, 2285-2293.

Turpin, D.H., 1991. Effects of inorganic $\mathrm{N}$ availability on algal photosynthesis and carbon metabolism. J. Phycol. 27, 14-20.

Weger, H.G., Turpin, D.H., 1989. Mitochondrial respiration can support $\mathrm{NO}_{3}^{-}$and $\mathrm{NO}_{2}^{-}$ reduction during photosynthesis. Interactions between photosynthesis, respiration, and $\mathrm{N}$ assimilation in the $\mathrm{N}$-limited green alga Selenastrum minutum. Plant Physiol. 89, 409-415.

Williams, P.J.I., Robertson, J.E., 1991. Overall planktonic oxygen and carbon dioxide rnetabolisrns: the problem of reconciling observations and calculations of photosynthetic quotients. J. Plankton Res. 13, 153-169.

Winter, A., Jordan, R.W., Roth, P.H., 1994. Biogeography of living coccolithophores in ocean waters. In: Winter, A., Siesser, W.G. (Eds.), coccolithophores. Cambridge Univ Press, pp. 161-177.

Wray, J.L., Filner, P., 1970. Structural and functional relationships of enzyme activities induced by nitrate in barley. Biochem. J. 119, 715-725.

Wurch, L., http://genome.jgi-psf.org/cgi-bin/dispGeneModel?db $=$ Emihu1\&tid $=430293$ 